\title{
FABP5 wt Allele
}

National Cancer Institute

\section{Source}

National Cancer Institute. FABP5 wt Allele. NCI Thesaurus. Code C51246.

Human FABP5 wild-type allele is located in the vicinity of $8 q 21.13$ and is approximately 4 $\mathrm{kb}$ in length. This allele, which encodes fatty acid-binding protein, epidermal, plays a role in fatty acid uptake, transport, metabolism, and keratinocyte differentiation. 